\title{
Escola e Democracia: diálogo e conflito
}

Eduardo Donizeti Girotto

Professor da Universidade do Oeste do Paraná

Doutorando em Geografia Humana pela USP

\section{Resumo}

Os avanços da democracia no Brasil não têm resultado num processo amplo de discussão sobre a cidadania, seus significados e realização. Este fato pode ser verificado pelo número cada vez maior de discursos que resumem o exercício da cidadania a participação nas eleições. O presente artigo tem como intuito discutir de que maneira a construção de outros fóruns de discussão e de participação popular podem possibilitar redefinições da democracia e da cidadania, que busquem fomentar a participação efetiva e a construção da esfera pública. Para tanto, analisa o papel que as escolas públicas da periferia paulista podem ter neste processo ao se tornarem lócus da construção da cidadania, com a implementação de um modelo de gestão democrática que, busque, através da construção coletiva do Projeto Político-Pedagógico, a real participação da comunidade e dos diferentes sujeitos que dela fazem parte.

Palavras-chave: Democracia; Educação Pública; Direito à Cidade.

\begin{abstract}
The progress of democracy in Brazil has not resulted in an extensive process of discussion of citizenship, its meaning and fulfillment. This fact can be verified by the increasing number of speeches which summarize the exercise of citizenship participation in elections. This article has the intention to discuss how the construction of other discussion forums and popular participation can enable redefinitions of democracy and citizenship, which seek to promote the effective participation and the construction of the public sphere. It analyzes the role that public schools on the outskirts of São Paulo in this process may have become the locus of citizenship building, with the implementation of a model of democratic management that seeks, through the collective construction of the Political-Pedagogical Project, the real community participation and the different subjects that are part of it.
\end{abstract}

Keywords: Democracy; Public Education; Right to the City. 


\section{Introdução}

s discussões produzidas acerca da escola pública e de seus
significados no mundo contemporâneo, muitas vezes, perdem
de vista o caráter sócio espacial da mesma, inserida em um contexto e um lugar. Apesar de seu caráter universal enquanto instituição criada com certos objetivos relacionados ao próprio desenvolvimento da modernidade (TIRAMONTI, 2005), a escola pública também apresenta particularidades decorrentes da relação que estabelece com os sujeitos e com o contexto no qual está inserido. Esta preocupação deve ser maior quando se propõe construir uma análise da escola a partir de um olhar geográfico, buscando levar em consideração sua espaço-temporalidade ligada a múltiplos processos em diferentes escalas geográficas.

Neste sentido, pensar a escola pública na atualidade a partir de um ponto de vista geográfico passa necessariamente pela compreensão e discussão sobre a forma como a mesma está organizada espaçotemporalmente, compreendendo as relações que a configuram, desvendando os interesses e as estratégias que a organização desta determinada espaçotemporalidade procura ocultar e a partir disso propor a construção de outra espacialidade, resultado do diálogo, da pesquisa, da participação de todos os agentes sociais responsáveis pela escola.

Para tanto, faz-se necessário precisar a escola, fugindo de meras abstrações que afirmam a existência de escolas irreais, configuradas por sujeitos que só existem nos livros e na imaginação daqueles que há um longo tempo não se encontram com esta realidade. Como aponta AZANHA (2001), há que se levar em consideração que toda escola possui um endereço. Apesar de parecer apenas uma afirmação despretensiosa, a mesma não tem sido considerada quando da elaboração de políticas públicas educacionais. Muitas vezes, tais políticas pressupõem escolas abstratas, com alunos e professores ideais, descontextualizados, apartados das tramas sócio espaciais que a configuram. A busca por controle e centralização, que muitos administradores públicos desejam realizar, resulta em políticas 
públicas fadadas ao fracasso porque incapazes de pensar as escolas enquanto múltiplas e diferenciadas. Tais políticas não levam em consideração as influências que a escola sofre e exerce não apenas na escala local, mas em outras escalas geográficas de realização das relações sócio espaciais.

Para que possamos compreender melhor os múltiplos processos espaços-temporais que contribuem para configuração da escola pública na sociedade brasileira contemporânea, faz-se necessário uma análise detalhada de ações que ocorrem em diferentes escalas geográficas. Cada uma destas ações, com maior ou menor intensidade, tem contribuído para definir as práticas sócio espaciais que configuram a escola. Vale, porém, ressaltar que não se trata de buscar uma causa global que explique a escola ou simplesmente analisá-la como realidade local, fechada em si mesma. O desafio desta análise está em compreender a configuração da escola enquanto espaço social situado e localizado, a partir das intersecções entre os diferentes agentes, ações, processos nas múltiplas escalas geográficas. A compreensão dos mesmos nos permitirá uma visão mais ampla e ao mesmo tempo detalhada das escolas que iremos analisar, bem como as possibilidades, limites e contradições das práticas sócio espaciais que ocorrem no interior das mesmas.

Neste sentido, na primeira parte deste artigo buscaremos discutir aquilo que consideramos serem as principais problemáticas que envolvem a escola pública e a democracia no Brasil, partindo do pressuposto de que tanto uma como outra são fenômenos recentes e em plena construção na sociedade brasileira. $\mathrm{Na} 2^{\circ}$ parte, apresentaremos algumas análises do significado da escola pública na periferia paulista feitas a partir de pesquisas realizadas durante os anos de 2006 e 2009 e que resultaram em dissertação de mestrado apresentada no Programa de Pós-Graduação em Geografia Humana da Universidade de São Paulo. Em ambos os momentos, interessanos compreender de que maneira se estabelece o diálogo e o conflito entre democracia e escola pública no Brasil. 


\section{A escola pública em um Estado por se fazer}

A escola pública ganha visibilidade na ordem atuais das coisas no Brasil. Basta um olhar um pouco mais atento para os diversos meios de comunicação para que esta constatação se torne efetiva. Ao mesmo tempo, porém, é possível perceber que tal visibilidade, joga luz muito mais sobre os problemas do que sobre os avanços da mesma. Ela é acusada, por todos os lados, por sua incapacidade de ensinar, educar, controlar, disciplinar... Enfim, por não cumprir todos os anseios projetados sobre ela pela sociedade. Mas é preciso ir além desta constatação para se compreender os processos e fenômenos relacionados que envolvem as transformações pelas quais vem passando a escola pública no Brasil nas últimas décadas, bem como analisar de forma atenta, séria e crítica as relações intrínsecas existentes entre as problemáticas que envolvem, ao mesmo tempo, a escola e a sociedade.

O Estado brasileiro, enquanto organização autônoma é uma conquista bastante recente. O processo violento de ocupação, exploração e destruição do território e das relações sociais aqui existentes, iniciado com os Portugueses ainda no século XVI, estendeu-se, de diferentes formas, por mais de 300 anos e ainda deixa marcas na dinâmica atual da sociedade brasileira. Além do endividamento econômico, das relações de dependência, tal processo trouxe elementos e valores sócio-políticos que definem as práticas e ações da população brasileira. O chamado "jeitinho brasileiro", que se expressa pela reprodução dos privilégios em detrimento dos direitos fundamentais é uma destas marcas deixadas pelo processo de construção sócio espacial do Brasil.

Em seu livro "Raízes do Brasil”, Sérgio Buarque de Holanda analisa uma das implicações deste processo no desenvolvimento das ações e do sentido do Estado Brasileiro. Para o autor,

no Brasil, pode-se dizer que só excepcionalmente tivemos um sistema administrativo e um corpo de funcionários puramente dedicados a interesses objetivos e fundados neste interesse. Ao 
contrário, é possível acompanhar, ao longo de nossa história, o predomínio constante das vontades particulares que encontram seu ambiente próprio em círculos fechados e pouco acessíveis a uma ordenação impessoal. Dentre esses círculos, foi sem dúvida o da família aquele que se exprimiu com mais força e desenvoltura em nossa sociedade. (HOLANDA, 2001, p.146).

Como terra do Rei, habitada por uma população retirada à força de sua terra natal e aqui colocada na condição de escravo, no Brasil pouco se concretizou o processo de diferenciação entre aquilo que diz respeito à esfera pública, os assuntos comuns e de responsabilidade coletiva, e a esfera privadas, dos domínios particulares. Durante o período colonial, a distinção entre público e privado era sempre resultado da vontade do rei que, no final das contas, era o efetivo dono não apenas das terras, mas das vidas dos que ali habitavam. Vale ressaltar que esta noção se assenta, juridicamente, na forma como o sistema de capitanias hereditárias estava organizado. Só com o consentimento do rei, as terras poderiam ser entregues aos capitães donatários que tinha por obrigação fazê-las produzir, ao mesmo tempo em que aumentavam a possibilidade de ocupação do território ao repassarem partes destas terras (sesmarias) a outros homens de sua confiança. Porém, juridicamente, apesar desta aparência de que as terras encontravam-se dispersas nos domínios de diferentes senhores, eram todas domínio do rei e, a qualquer momento, poderiam retornar-lhe.

Com esta configuração jurídica feudal, e com a implantação do trabalho escravo, forma-se no Brasil, desde o princípio, uma confusão entre a esfera pública e a privada, sendo o direito substituído pela força da coerção e da violência. O homem cordial, apontado por Sérgio Buarque de Holanda, é resultado deste processo. Não se trata do cordial como elemento pacificador ou coisa que o valha, mas da paixão e da violência dela resultante sobrepujando a tolerância. Mesmo com a implementação de avanços democráticos em muitas das leis aprovadas nas últimas décadas (CF 1988, ECA, LDB) permanece nas ações e práticas da sociedade brasileira o privilégio em detrimento do direito. Neste sentido, é possível 
afirmar que a construção da esfera pública na qual os homens e mulheres se encontram iguais em direitos e oportunidades ainda é uma realidade distante de ser alcançada no Brasil.

Outro elemento de nosso passado colonial que contribuiu de forma significativa para a não construção de uma esfera pública na sociedade brasileira diz respeito ao processo perverso de escravização. Como prática que perdurou por quase 350 anos, sua presença ainda se mantém viva nas relações políticas e sociais. Transplantados de suas terras em péssimas condições, tratados como mercadoria, a população negra no Brasil foi sempre colocada à margem do direito. Não se constituíam enquanto cidadãos do país e, portanto, encontravam-se apartados das condições mínimas de dignidade garantidas a um cidadão daquele tempo. Vale ressaltar que mesmo após o processo de abolição da escravatura, as mentalidades e práticas das elites econômicas e políticas do país permaneceram semelhantes àquelas encontradas durante o período da escravidão. Não houve um processo de ampliação aos negros dos direitos previstos a todos os homens livres. Com isso, mesmo libertos, milhares de negros continuaram a margem da sociedade, em condições semelhantes ou piores aquelas encontradas no período da escravidão.

Em um dos mais importantes estudos sobre a escravidão no Brasil, COSTA (1998) aponta as contradições que marcaram o desenvolvimento do processo de abolição no Brasil. Para autora, assim como em outros momentos da história política do Brasil, houve um processo de mudança sem ruptura, de transformação com permanência. Para a autora,

\footnotetext{
A abolição não correspondeu tampouco às expectativas dos abolicionistas. Ao contrário do que estes esperavam, ela não representou uma ruptura fundamental com o passado. As estruturas arcaicas de produção, a economia essencialmente monocultora e de exportação, vulnerável às oscilações do mercado internacional, o monopólio da terra e do poder por uma minoria, a miséria e a marginalização política e econômica da grande maioria da população, as formas disfarçadas de trabalho forçado e as precárias condições de vida do trabalhador rural sobreviveram à abolição. Realizada principalmente por brancos e negros ou mulatos pertencentes à sua clientela,
} 
legitimada por um ato do parlamento, ratificado pelas classes dominantes, a abolição libertou os brancos do fardo da escravidão, abandonando os ex-escravos à sua própria sorte. (COSTA, 1998, p.47).

Este trecho revela, em nossa perspectiva, um dos aspectos fundamentais que marca a história e a geografia política de nosso país, que seja, o fato de todas as principais transformações nele ocorridas se darem de forma lenta, articulando interesses de grupos políticos e econômicos divergentes. Neste processo, duas ou mais classes sociais se articulam em torno de interesses e estratégias comuns para assim manterem distantes do poder àquelas classes que podem, de alguma forma, romper com os seus privilégios estabelecidos. Para MARTINS (1999), é isto o que configura no Brasil o de poder do atraso.

Quando se reconhece que a sociedade brasileira, como outras sociedades de origem colonial, com problemas similares, é uma sociedade de história lenta e se toma essa constatação como perspectiva de interpretação da realidade social, os resultados são diferentes do que se consegue por outro meio. A perspectiva do que possa chamar de uma sociologia da história lenta permite fazer uma leitura dos fatos e acontecimentos orientada pela necessidade de distinguir no contemporâneo a presença viva e ativa de estruturas fundamentais do passado. (p. 36)

Esta sociologia da história lenta pode ser ampliada se incluirmos também uma geografia desta mesma história. A análise dos processos históricos e geográficos que marcam a sociedade brasileira contemporânea tem suas origens em diferentes práticas do passado, mas que não dão se forma homogênea espaço-temporalmente. Faz-se necessário levar em consideração o fato de que diferentes processos históricos ganham contornos diversos em decorrência do lugar e das condições geográficas no qual se desenvolvem. No caso da educação pública brasileira é fundamental que acentuemos esta diversidade geográfica que a mesma assume no país. Não se pode falar da escola pública brasileira como realidade única, indiferenciada. São múltiplas as suas formas de organização e de articulação e desta capacidade de compreendermos este fenômeno que a pesquisa poderá ocorrer de forma mais serie e substancializada. 
Como pensar, portanto, esta escola pública brasileira em um estado ainda por fazer? Quando afirmamos que o Brasil é um Estado ainda por se fazer levamos em consideração que as experiências de organização territorial do país ocorridas até o presente momento são todas de caráter autoritário, seja o autoritarismo da força explicita, como ocorrida nas ditaduras militares, quanto o populismo encontrado em diferentes períodos e lugares na história do país. Ambas as experiências de organização do Estado pressupõem a supressão da sociedade civil, das formas e dos movimentos organizados da população que, mesmo de forma contraditória, buscam reformular as noções diretamente relacionadas ao poder. Ao suprimir a sociedade civil ou transformá-la em algo homogêneo com o intuito de ocultar o privilégio de algumas classes sociais em detrimentos das demais, o Estado Brasileiro age no sentido de enfraquecer as possibilidades de construção de uma esfera pública, condição sine qua non para que a democracia no Brasil possa se consolidar para além desta experiência pseudodemocrática que ora vivenciamos.

\section{A luta pela educação pública na periferia paulista}

Em certa medida, a luta pela educação pública no Brasil engendra uma tentativa de se criar as condições para que a sociedade civil se desenvolva e com ela a possibilidade de uma democracia mais participativa. Um dos exemplos desta luta pela educação pública no Brasil pode ser encontrado na periferia paulista, na década de 1980. Em um contexto de espoliação urbana (KOWARICK, 1979), de reprodução crítica do modo de produção capitalista, que tem na periferia paulista uma das suas formas de realização, surgiram diversos movimentos de luta pela educação. Em sua obra “A ilusão fecunda”, SPOSITO faz um estudo detalhado das condições e dos processos que resultaram no surgimento deste movimento. Para além de uma leitura que busca entender a luta pela educação como um fim em si mesmo, a autora busca compreender de que forma tal movimento articula as diferentes reivindicações com a problemática urbana ali presente. Para a autora, 
as dificuldades de acesso a terra, transformando São Paulo em uma cidade clandestina do ponto de vista da situação legal, trouxeram novas demandas por equipamentos escolares em bairros ainda inexistentes para o poder público, demandas cada vez mais limitadas pelos problemas do uso privado do solo. (SPÓSITO, 1993, p. 53)

Em situação de clandestinidade, enquanto produtos e agentes do processo de urbanização crítica, os moradores da periferia paulista iniciam um processo de movimento que, em certa medida, busca resgatar o sentido do espaço para além da lógica do capital. Não se trata apenas da construção de escolas ou da instalação dos bens e equipamentos urbanos necessários. Há um amplo movimento de afirmação da sociedade civil, de uma tentativa de controle mais direto dos processos e ações que envolvem as decisões do Estado. Naquele momento, as mulheres (que eram as principais organizadoras dos movimentos de luta pela educação), ao lutarem pelos direitos de seus filhos pela educação, passavam a compreender que o Estado era também um dos agentes do processo de espoliação urbana. Era através dos investimentos que realizava (ou que não realizava) que a desigualdade sócio espacial era acentuada. Por que as escolas das periferias não podiam ser dotadas das mesmas condições de escolas situadas em bairros mais privilegiados da cidade de São Paulo? Ao se questionarem nestes termos, estas mulheres passaram a entender que o Estado não representava os interesses de toda a população, mas os de apenas algumas classes sociais, que tinha mais poder econômico para pressioná-lo. E, ao entenderem isso, suas lutas se ampliaram. Não se tratava mais apenas do direito a educação. A luta é também por saúde, cultura, transporte e, em certa medida, pela participação ativa dos mais pobres nas decisões que afetam sua vida.

Em certa medida, o que está em jogo naquele contexto, o que de fato ele expõe, são as múltiplas contradições e os próprios limites da reprodução da sociedade urbano-industrial. Como vimos, ao lutarem pelo direito a educação, tais moradores buscam inverter a lógica da espoliação urbana que os levou a habitar os limites do urbano, em um contexto no qual a cidade, enquanto encontro, possibilidade, criação, já não está presente. O movimento pela educação, articulado com os outros movimentos sociais, é, 
portanto, mesmo que parcial, uma luta pelo direito à cidade (LEFEBVRE, 2004) pelo direito ao urbano que só se pode realizar a partir da superação das contradições que marcam a reprodução social.

Neste sentido, a partir deste exemplo podemos compreender que o significado da escola pública na periferia paulista se configura, também, enquanto resultado da luta pela reapropriação do espaço para além da lógica do capital. Mesmo que de forma parcial, trata-se da conquista e realização de um direito, de uma mudança de perspectiva. Neste processo de luta pelo direito à cidade, a crítica a urbanização está posta, mesmo que ainda em processo inicial. Aos poucos, como pudemos perceber pelas descrições feitas por SPOSITO, os participantes destes movimentos passam a reivindicar não mais apenas o direito a educação, mas a todas as infraestruturas necessárias para que a cidadania plena possa ser realizada. Tal luta, portanto, transforma-se em uma luta pelo direito à cidade.

As exigências dos equipamentos de uso coletivo, ao propiciarem o aparecimento das lutas sociais, transformam seus protagonistas - trabalhadores, mulheres, jovens e crianças. Há um acúmulo de experiências, redes de sociabilidades se desenvolvem e nessa trajetória já não mais se torna possível a compreensão em profundidade de um dos aspectos da luta social - as demandas educativas - se ele não estiver articulado às demais formas de enfrentamento desenvolvidas pelas classes populares moradoras da periferia urbana da cidade de São Paulo. (SPÓSITO, 1993, p.53)

O exemplo descrito por Spósito é uma das múltiplas trajetórias espaço-temporais da relação entre escola pública e democracia no Brasil. Como vimos, é resultante deste Estado por se fazer que não se consegue garantir a todos os seus cidadão o direito a cidadania plena que se realiza tem bem pelo acesso a educação pública.

\section{Do espaço da luta ao espaço da alienação}

Para além do significado enquanto espaço de luta e conquista social apontado na pesquisa de Spósito, a escola pública na periferia paulista pode assumir funções fundamentais para a reprodução das contradições que 
marcam a sociedade brasileira contemporânea. Em nossa pesquisa, buscamos compreender tais contradições a partir dos significados de uma escola pública localizada na periferia de São Paulo, no bairro de Sapopemba. A escolha deste local está diretamente relacionada às vivencias e práticas profissionais do pesquisador, morador do bairro há 28 anos e docente da rede municipal de ensino na região por três anos. Para que possamos iniciar o nosso diálogo, faz-se necessário a contextualização da realidade a qual propomos analisar.

Observemos o mapa a seguir:

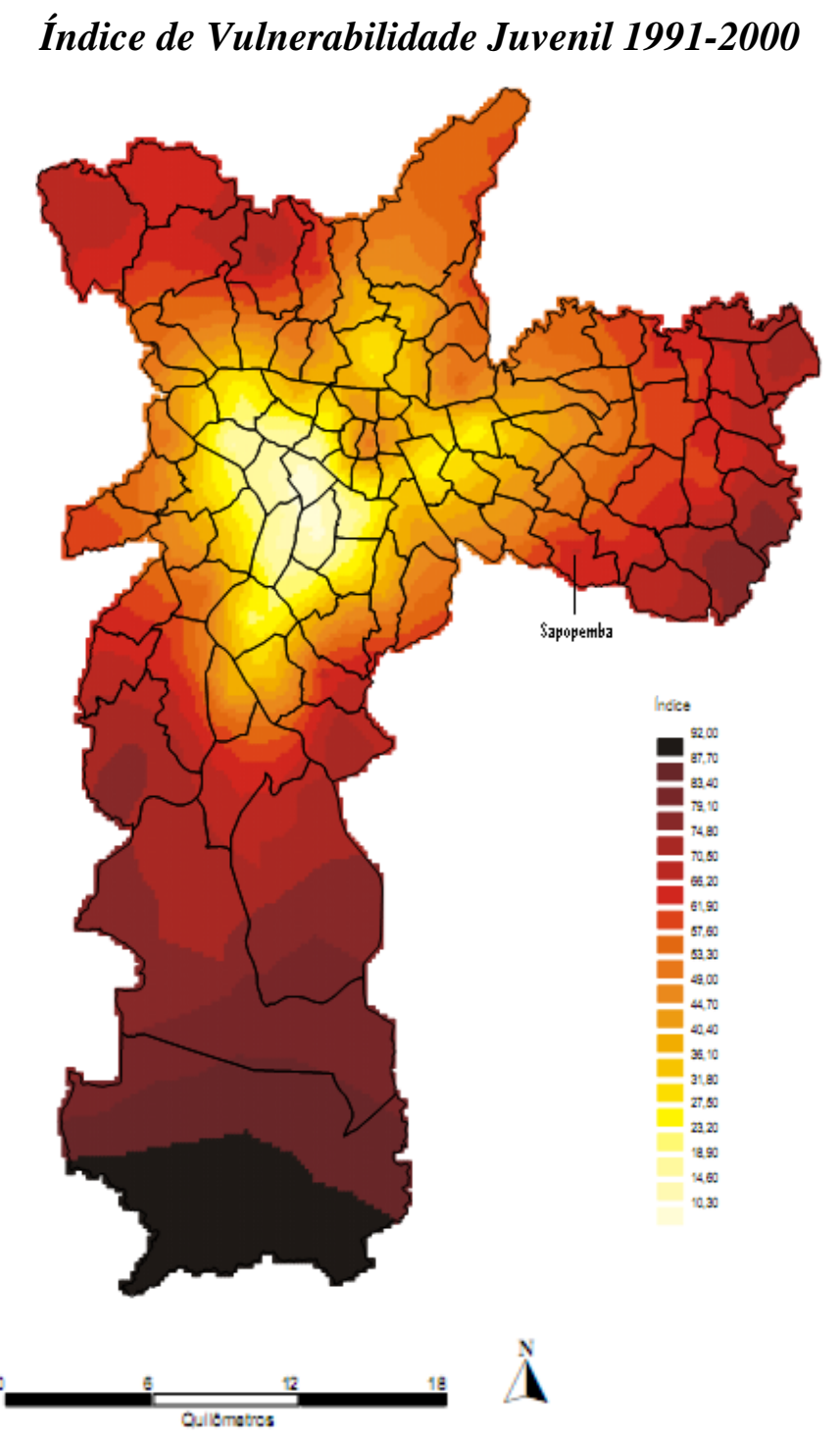

Fonte: Site da Prefeitura de São Paulo: Município em Mapas. Disponível em http://www9.prefeitura.sp.gov.br/sempla/mm/index.php?texto=corpo\&tema_cod=4, Acessado em 18/07/2008. 
O mapa acima, produzido pela Prefeitura de São Paulo, leva em consideração seis variáveis (taxa anual de crescimento demográfico no período intercensitário 1991-2000; participação de jovens entre 15 e 19 anos na população do distrito; taxa de mortalidade por homicídio da população masculina entre 15 e 19 anos; participação de mães adolescentes, de 14 a 17 anos, no total de nascidos vivos; rendimento nominal médio mensal do chefe do domicílio; porcentual de jovens entre 15 e 17 anos que não frequentam a escola) para definir o Índice de Vulnerabilidade Juvenil de cada um dos distritos que compõem a cidade de São Paulo. O índice varia de 0 a 100, sendo que, quanto mais próximo de 100, maiores são os riscos aos quais os jovens estão expostos.

Como podemos perceber, o distrito de Sapopemba, local onde se situa a escola pública estudada, apresenta um alto índice de Vulnerabilidade Juvenil (entre 60 e 70 pontos), o que pode ser verificado com uma simples caminhada pelo bairro. Faltam opções de lazer e de cultura; as escolas e os postos de saúde estão depredados; as áreas verdes vêm sendo paulatinamente substituídas por pontos de comércio; o adensamento populacional tem aumentado sem uma ampliação dos investimentos sociais na região, o que tem contribuído para uma diminuição da qualidade de vida no bairro. Estes elementos, somados a uma série de outros verificados, permite-nos compreender esta ausência do Estado em uma série de elementos que garantiriam a realização dos direitos fundamentais aos moradores deste bairro.

Esta ausência do Poder Público na garantia dos direitos fundamentais dos moradores da periferia resulta em um processo de ampliação da violência juvenil, que pode ser verificado principalmente quando analisamos a atuação do tráfico de drogas entre os jovens nos bairros mais periféricos. Como podemos constatar em nossas práticas cotidianas e a partir das pesquisas realizadas, o tráfico de drogas está presente de forma intensa na vida dos jovens que, com a crise da sociedade do trabalho, que tem na periferia sua marca mais latente, o veem como possibilidade de ascensão social. Em certa medida, a inserção no tráfico de drogas significa, para 
muitos jovens, visibilidade social em um mundo marcado pela invisibilidade das fronteiras que separam centro-periferia. É pelo tráfico que podem ter acesso ao mundo da mercadoria, que podem se inserir, mesmo que de forma precária, como consumidores, visto que a eles é negado o direito à cidade. Se já não podem ter seus direitos fundamentais garantidos, se a presença do Estado só se faz perceber a partir da violência policial, resta-lhes, como principal opção o tráfico de drogas, caminho mais rápido para ascensão social e a obtenção das "mercadorias dos sonhos" - o tênis, o celular - que lhes permitem maior aceitação social. A ausência do poder público, em certo sentido, resulta também no fracasso da escola em garantir alguma perspectiva de futuro aos jovens que a ela recorrem diariamente, pois é da falta desta perspectiva de futuro e de um significado mais amplo da escola que avança o tráfico de drogas e suas promessas de um mundo melhor, marcado pela negação do cidadão em favor do consumidor.

Ao mesmo tempo, esta ausência do poder público em tantas áreas deste bairro da periferia paulista transforma, muitas vezes, a escola pública em um dos únicos lugares ao qual, principalmente os jovens, recorrem como única opção de acesso a algum tipo de bem cultural. Cabe à escola pública, portanto, neste contexto, garantir aos jovens o mínimo de acesso aos bens culturais e sociais e possibilitar o desenvolvimento ao direito à cidade, mesmo que de forma parcial. Além disso, esta ausência do Estado por meio de outros órgão e instituições potencializa o papel da escola pública enquanto lugar da visibilidade do poder estatal. Com aponta ALGEBAILE (2009),

de fato, a gradativa distribuição da escola no território nacional não ocorreria desvinculados de contextos de organização institucional nos quais a possibilidade de presença da escola ensejava definições acerca da ausência ou das formas de presença de outras instituições, serviços e ações. A presença da escola em lugares marcados por ausências conferiu a essa instituição um sentido estratégico excepcionalmente amplo (p.128)

Neste sentido, para além apenas de sua função de fornecer educação formal, a escola pública na periferia acabou por desenvolver funções que 
caberiam a outros órgãos dos setores públicos e privados que, por falta de motivações econômicas, não o realizam. O exemplo a seguir pode ajudar a entender melhor esta problemática.

Lembro-me que, na primeira reunião de pais em que participei como Professor de Geografia da escola pública municipal a qual este texto se refere, percebi uma ausência dos pais. Apenas dois pais participaram da reunião. Alguns dias depois, em um sábado pela manhã, fui designado, juntamente com outros colegas professores, para fazer a distribuição de leite aos alunos. Esta distribuição fazia parte de um programa da Prefeitura de São Paulo que ficou popularmente conhecido como "Leve Leite”. Neste programa, cada criança recebe cinco latas de leite em pó por mês, dependendo de sua frequência escolar. Para retirar o leite, as crianças precisam do acompanhamento de um adulto responsável. Foi então que me veio a surpresa: naquele sábado, pude conhecer a quase totalidade dos pais dos alunos para os quais leciono. Pude, em conversas rápidas, saber um pouco mais de cada um deles, seus problemas, bem como dialogar com os pais sobre algumas questões relacionadas à aprendizagem dos alunos. Aquilo que buscava alcançar durante a reunião de pais, pude realizar por meio da distribuição de leite.

Confesso que, de pronto, não me veio à tona a reflexão que agora transformo em texto. Talvez, faltava-me ainda esta indagação: qual o significado da escola pública naquele lugar? Na periferia, a educação é questão secundária da escola. Ali, a escola é antes presença do Estado que, em quase tudo, está ausente. É a marca do Estado - e não de qualquer tipo, mas do Estado patrimonialista, marcado pela confusão entre público e privado - que ali se faz perceber e pelo qual esperam pais, filhos, comunidade, que vão em direção à escola.

$\mathrm{Na}$ periferia, marcada em quase tudo por intensos processos de expropriação, a função primordial da escola pública é a de contenção social. A escola surge como proteção contra o lugar, visto por muitos como vazio e desprovido de sentido. A escola já não é possibilidade de mudança de lugar. 
Há muito tempo perdeu este papel. O discurso do mercado não tem tanta força quando três ou quatros gerações de uma mesma família estão à margem dele. A escola apenas protege do lugar. Os muros são cada vez mais altos. Investe-se em grades, sistemas de segurança, mas mesmo assim, a biblioteca, recém-inaugurada, é assaltada. O lugar toma de assalto a escola, invade-a; aos poucos derruba os muros que são erguidos exatamente para afastar os perigos que o lugar representa.

Em um lugar marcado pelas contradições da expansão capitalista da cidade e do urbano, em sua forma crítica, a escola surge como materialização destas contradições, como apaziguamento e crise, como contenção e implosão social. Não é com o objetivo de alcançar educação formal que a maioria dos pais manda seus filhos para a escola; fazem-no para que se sintam seguros ao ter onde deixarem os filhos quando forem trabalhar. Mas aqui é preciso fugir de visões maniqueístas do problema. Antes, faz-se necessário compreender as seguintes questões: qual o significado da educação formal numa sociedade marcada pela crise do trabalho que encontra na periferia o seu lado mais crítico? Por que lutar por educação formal de qualidade para um possível futuro melhor, se a própria perspectiva de futuro não existe? Como aponta BAUMAN (2005),

é verdade que a desconcertante volatilidade da posição social, a
redução de perspectivas, o viver ao deus-dará, sem uma chance
confiável de assentamento duradouro, ou pelo menos de longo
prazo, a imprecisão das regras que se deve aprender e dominar
para ir em frente - tudo isso assombra a todos eles, sem
discriminação, gerando ansiedade, destituindo todos os
membros dessa geração, ou quase todos, da autoconfiança e da
auto-estima. (p.23)

Neste sentido, para os pais, o que interessa é cobrar da escola ações no presente, que resolvam questões emergenciais. É preciso afastar as crianças das drogas, do tráfico, da violência, enquanto são obrigados a atravessar a cidade, em ônibus lotados para se reproduzirem enquanto trabalhadores subalternos, precários, reproduzindo assim as contradições inerentes ao modo de produção capitalista. Como pensar a educação sem existência de perspectiva? Como transplantar discursos e práticas realizadas em escolas 
localizadas em bairros de classe média para a periferia de São Paulo? Quem assim age se esquece de que, para além do discurso, a educação só acontece situada e contextualizada.

Em nossa pesquisa, pudemos constatar a ações de alguns professores que buscam romper com esta lógica de fechamento da escola. Convidam o lugar a participar da escola. Ao invés dos muros, escancaram os portões, convidam os alunos às praças e a comunidade para dentro da escola. Em certa medida, rompem os limites entre a escola e o lugar. O que podemos perceber em nossa pesquisa é que os professores que assim agem são também parte do lugar. Suas vidas estão ali. Não escolheram ao acaso lecionar naquela escola; foi antes ação política. Veem, em suas atuações na escola, a redefinição do seu lugar e, portanto, entendem-no como aliado, como pertencente ao que são ao que pensam, e ao que fazem.

Mas muitos dos professores não estão ali pelo lugar, não pertencem e não querem dele fazer parte. Desenraizados que estão, reproduzem a lógica do desenraizamento presente na escola da periferia e a transformam de espaço da luta em lugar da alienação, no qual os agentes do poder podem reproduzir seus interesses e privilégios.

Neste sentido, a compreensão do significado da escola pública na periferia pressupõe o entendimento de que, no mundo contemporâneo, a alienação do capital só pode se realizar com a alienação do lugar. É nos homens desenraizados, professores e alunos, que a alienação do lugar pode se reproduzir. E com ela, diminui a possibilidade da realização de uma democracia plena, marcada pelo direito de todos os homens e mulheres a pensarem e construírem o lugar em que vivem.

\section{Reconstruir a escola para reconstruir o lugar}

A partir disso, faz-se necessário mudar as relações entre os diferentes sujeitos da educação com a escola e o lugar, buscando construir novos significados e novas práticas sócio espaciais que visem o bem comum e o diálogo criativo na solução de problemas. Para tanto, tais ações passam 
necessariamente pela discussão da gestão democrática da escola, pela construção de fóruns reais e efetivos de participação popular que resultem em uma maior discussão e organização coletiva do espaço público. As relações e os conflitos que resultam da relação entre escola, lugar e democracia, antes de serem negados, devem se tornar objetos de discussão e de construção do diálogo e do debate.

Entre os fóruns que acreditamos possuírem esta potencialidade de lócus de exercício real e efetivo da cidadania estão o Conselho de Escola e a construção coletiva do Projeto Político Pedagógico. Enquanto órgão máximo de decisão da escola, o Conselho reúne a diversidade da comunidade escolar e torna-se, portanto, fórum propício para o surgimento dos conflitos e a resolução dos mesmos por meio do diálogo e do desenvolvimento do espírito público. O Conselho de Escola surge com um dos possíveis fóruns efetivos de participação da comunidade escolar e, consequentemente, de implantação de um processo de Gestão Democrática na qual todos os sujeitos da educação tenham garantidos os seus direitos de decidirem sobre quais princípios devem nortear a escola da qual fazem parte.

Tais princípios, por sua vez, devem estar explícitos no Projeto Político Pedagógico (PPP) da Escola. A construção coletiva de tal tem o poder de revelar interesses e intenções que, em um primeiro momento, ficam ocultas nas relações sócio espaciais que ali ocorrem. Como nos aponta Vasconcellos (2007), o PPP consiste na forma como a comunidade escolar, a partir de seus diferentes sujeitos, compreende e se relaciona com o lugar e com o mundo a partir da educação. No PPP estão explícitos os alicerces que sustentam as práticas pedagógicas e sócio espaciais daquela certa situação e contexto. Define as relações dos sujeitos e as concepções que a permeiam. Por se tratar de uma construção coletiva, não pode ser pensada sem a ocorrência do diálogo e do conflito. Em certa medida, o PPP é o resultado das negociações que atravessam os diversos interesses que emergem da relação entre escola, sujeito e lugar e, portanto, revelador das implicações que a permeia. 
O PPP traz para o interior da escola a problemática do lugar que, muitas vezes, pelo medo do entorno, por práticas sucessivas de fechamento ou por receio daquilo que o lugar pode revelar, não é levado em consideração na definição de práticas pedagógicas. Ao invés de negar o lugar em suas múltiplas implicações, o PPP reafirma a ligação intrínseca entre lugar e educação, encarando a mesma como elemento fundamental de inserção da escola e dos seus sujeitos no mundo. É a partir do reconhecimento do lugar, de suas implicações, das práticas sócio espaciais que ele sustenta e pelas quais é sustentado que a comunidade escolar, em suas reais condições de existência, pode definir caminhos, visões, projetos que se articulem ou se contraponham aos modelos e estratégias advindas de cima para baixo e que remetem a outras lógicas, à outros interesses que não aqueles vinculados a ideia de democracia e de bem público.

Dessa forma, quando pensamos na importância da construção coletiva do PPP e das discussões no interior do Conselho de Escola como elementos fundamentais na construção da autonomia e da gestão democrática da unidade escolar, o fazemos buscando resgatar aquilo que há de geográfico nesta questão, que seja, o fato de que o PPP e o Conselho surgem também de um diálogo crítico e criativo entre escola e lugar. O PPP situa a escola e seus sujeitos, permitindo aos mesmos o olhar sobre o mundo a partir de um lugar, que não é, porém, o único. O Conselho cria as bases e ações necessárias para que a realização da cidadania não se torne discurso vazio, mas tenha realidade prática. Se o PPP traz o lugar para a escola, o Conselho cria as possibilidades da efetivação da mesma enquanto lugar público, responsabilidade de todos, porque resultado do trabalho comum. A reconstrução constante do Projeto Político Pedagógico como prática presente em uma escola democrática possibilita aos sujeitos repensarem constantemente os lugares e as situações de onde falam e de onde se relacionam com o mundo. É também oportunidade de realização da cidadania, no sentido em que envolve a participação e a construção crítica e criativa de um projeto de ação que visa assegurar direitos alienáveis do cidadão. Como lócus da construção coletiva deste projeto, a escola, em certa 
medida, passa por um processo de ressignificação, no qual, à sua função educativa, vem somar uma série de outras funções que dizem respeito ao exercício da cidadania e a realização da democracia.

Neste sentido, a escola pública, principalmente na periferia, ao revelar as contradições de uma estrutura política baseada nos privilégios e não nos direitos, pode se tornar lócus da reconstrução da cidadania, permitindo a cada um dos sujeitos modificar as relações que estabelece com o mundo público. Para além de espaço estatal, lugar da alienação, a escola reapropriada, espaço de lutas, torna-se pública, porque resultado das negociações, dos diálogos construídos entre os diferentes sujeitos que dela participam. Para além do lugar do paternalismo, dos programas assistenciais, da violência em suas diferentes formas torna-se lugar de realização do direito à cidade, direito ao encontro e a possibilidade de se identificar, na fala dos seus pares e na ação coletiva em prol do bem comum.

Para tanto, faz-se necessário, para se inverter esta lógica do desenraizamento, da presença-ausência do Estado, verificada na periferia, a reconstrução da vida ativa, do significado da ação em contraposição a fabricação, o rompimento crítico pela palavra-discurso-ação que se faz em conjunto, no diálogo com o outro, na afirmação do espaço da aparência, utilizando-nos dos conceitos de Hannah Arendt ${ }^{1}$. Para tanto, faz-se urgente uma nova política de espacialidade, como nos aponta Massey (2008), que requer um reconhecimento de outro espaço, marcado pela subjetividade, pelo encontro de múltiplas trajetórias que se, num primeiro momento, são múltiplas apenas na aparência porque totalizadas pela lógica do capital, a partir do encontro, do diálogo criativo, da ação conjunta, se realizam enquanto múltiplas e unas.

Neste sentido, o espaço precisa ser pensado e realizado enquanto lócus da possibilidade, da abertura, do diálogo e do conflito. Uma nova política

\footnotetext{
${ }^{1}$ Para Arendt (2008:192), "na ação e no discurso, os homens mostram quem são, revelam ativamente suas identidades pessoais e singulares, e assim apresentam-se ao mundo humano, enquanto suas identidades físicas são reveladas, sem qualquer atividade própria, na conformação singular do corpo e no som singular da voz.".
} 
espacial requer outra espacialidade da política, outra configuração das relações sociais, uma redefinição dos homens não mais como mercadorias, mas enquanto seres sociais nascidos a partir da ação. Pensar a escola na periferia nesta nova política da espacialidade passa, necessariamente, por pensar a construção do espaço público e a reconstrução do senso comum. Identificados os interesses predominantes hoje na escola e seus principais agentes, é preciso destituí-los como únicas trajetórias possíveis, assim como quer que pensemos os agentes da reprodução do capital. Por mais insuficiente que seja tal ação, é ela, por enquanto, possível e necessária. E, dessa forma, é ela que precisamos realizar se assumirmos de fato os compromissos que, enquanto seres humanos, nos propusemos.

\section{Considerações Finais: "Para não dizer que não falei da flor"}

Para encerrar, gostaria de contar e compartilhar um episódio que marcou intensamente a minha carreira de professor de geografia.

Regiane tem 11 anos. Quer ser jogadora de futebol. É aluna da quinta série da escola pública objeto desta pesquisa.

A primeira vez que falei com Regiane foi durante a correção de uma atividade relacionada à noção de lugar. Havia pedido que os alunos listassem todos os lugares pelos quais já haviam passado em sua vida e que escolhessem um que gostaram mais para escrever detalhadamente sobre ele. Regiane, uma menina magra, cabelo encaracolado, morena, rosto repleto de sardas, aparelhos nos dentes, veio até a minha mesa mostrar a lição. Havia listado em seu caderno uma série de nomes de lugares que já tinha visitado. Entre eles, constava o da cidade de Presidente Bernardes. Indaguei-a sobre o que tinha ido fazer lá. “Fui visitar o meu tio que está preso”, respondeu, sem nenhum tipo de constrangimento. "Você gostou da cidade?”, continuei. “Gostei”. “Eu conheço aquela região. Já visitei Presidente Prudente”, afirmei, tentando expandir a conversa. “Ah, professor, eu conheço aquela região toda. Já fui a tanto presídio que nem me lembro mais”, encerrou a 
menina, se dirigindo ao seu lugar, com o sorriso no rosto e nenhuma preocupação, deixando para trás um professor perplexo e desconstruído.

Mas ali, sem saber, ela havia me ensinado uma grande lição: a da necessidade de estarmos sempre em processo de construção de conhecimento. Naquele momento, depois daquela fala, muitas de minhas teorias, desenvolvida anos a fio na Universidade já não serviam mais. Era preciso reconstruí-las a partir do contato diário e atento com aqueles meninos e meninas que vinham diariamente de suas casas em busca de algo que, a todo o momento precisamos estar atentos para entender.

O sorriso de Regiane, acompanhado de sua simplicidade frente à vida, foi um dos momentos em que o descaso, a falta de investimentos, o imobilismo, a desmotivação que tem marcado as escolas públicas principalmente nas periferias deste país e que fazem, diariamente, milhares de professores desistirem, foram substituídos pela vida em abundância. Não se trata de otimismo ingênuo ou coisa que o valha; trata-se de reconhecer nos homens e mulheres, apesar de tudo e ainda, as forças que vão para além da alienação.

Que a escola possa se tornar um dos lócus dessa nova política da espacialidade, marcada pelo encontro e pela solidariedade. Que assim como a história em Paulo Freire é o campo das possibilidades humanas, a Geografia também o possa ser. Que neste outro espaço, outros homens possam nascer, não como simulacros nem como resíduo, mas como a flor que rompe o asfalto do poema da vida descrito por Drummond:

(...) Uma flor nasceu na rua!

Passem de longe, bonde, ônibus, rio de aço do tráfego.

Uma flora ainda desbotada

Ilude a polícia, rompe o asfalto.

Façam completo silêncio, paralisem os negócios,

Garanto que uma flor nasceu.

Sua cor não se percebe.

Suas pétalas não se abrem.

Seu nome não está nos livros.

É feia. Mas é realmente uma flor.

Sento-me no chão da capital do país às cinco horas da tarde 
E lentamente passo a mão nessa forma insegura Do lado das montanhas, nuvens maciças avolumam-se Pequenos pontos brancos movem-se no mar, galinhas em pânico

É feia. Mas é uma flor. Furou o asfalto, o tédio, o nojo e o ódio.

(A Flor e a Náusea)

\section{Referências Bibliográficas}

ALGEBAILE, E. Escola pública e pobreza no Brasil. Rio de Janeiro: Lamparina/Faperj, 2009.

ANDRADE, Carlos Drummond de. Antologia Poética. $43^{\circ}$ edição. Rio de Janeiro: Record, 1999.

ARENDT, Hannah. A condição bumana. $9^{\circ}$ edição. São Paulo: Forense Universitária, 2008.

AZANHA, J. M. P. "Uma reflexão sobre a formação do professor da escola básica" In Estudos Avançados. Edição especial, volume 15, número 42, maioagosto de 2001.

BAUMAN, Zygmunt. Vidas Desperdiçadas. Rio de Janeiro: Jorge Zahar, 2005.

CARLOS, Ana Fani Alessandri. O lugar no/ do Mundo. São Paulo: Hucitec, 1996.

COSTA, E. V. da. Da senzala à Colônia. $4^{\circ}$ edição. São Paulo: Fundação Editora da Unesp, 1998.

DAMIANI, Amélia Luisa. "O lugar e a produção do cotidiano" In: CARLOS, Ana Fani Alessandri. Novos Caminhos da Geografia. São Paulo: Contexto, 2002. A cidade (des) ordenada: concepşão e cotidiano do conjunto habitacional Itaquera I. Tese de Doutorado. São Paulo: FFLCH-USP, 1993.

FREIRE, P. e SHOR, I. Medo e Ousadia: cotidiano do professor. $2^{\circ}$ edição. São Paulo: Paz e Terra, 1987.

GIROTTO, E. D. Escola, Lugar e Poder: as aventuras de um professor-pesquisador entre o subúrbio e a periferia. Dissertação de Mestrado. São Paulo: FFLCH, 2009.

HOLANDA, S. B. de. Raízes do Brasil. $26^{\circ}$ edição. São Paulo: Cia das Letras, 2001.

KOWARICK, L. A espoliação urbana. Rio de Janeiro: Paz e Terra, 1979. 
KURZ, Robert. O Colapso da Modernização. $5^{\circ}$ edição. São Paulo: Paz e Terra, 1999.

LEFEBVRE, H. O Direito à Cidade. $3^{\circ}$ edição. São Paulo: Centauro, 2004.

MASSEY, Doreen. Pelo espaço. Uma nova politica de espacialidade. Rio de Janeiro: Bertrand Brasil, 2008.

NAKANO, A. K. 4. COHABS da Zona Leste de São Paulo: território, poder e segregação. Dissertação de Mestrado. São Paulo: FAUUSP, 2002

SPOSITO, M. P. A ilusão fecunda. São Paulo: Hucitec/EDUSP, 1993.

TIRAMONTI, Guilhermina. "La escuela em la encrucijada del cambio epocal". In: Educação e Sociedade. Campinas, vol.26, n. 92, p.889-910, Especial - Out. 2005.

VASCONCELLOS, Celso dos S.. Planejamento. Projeto de Ensino Aprendizagem e Projeto Politico-Pedagógico. $17^{\circ}$ edição. São Paulo: Libertad, 2007. 